\title{
Surveillance and distribution of the emergent Sri Lankan cassava mosaic virus in China
}

\author{
Duan Wang ${ }^{1,2}$, Guixiu Huang ${ }^{3}$, Tao Shi ${ }^{3}$, Guofen Wang ${ }^{3}$, Rongxiang Fang ${ }^{1,2}$, Xuan Zhang ${ }^{1 *}$ and Jian Ye ${ }^{1,2^{*}}$
}

\begin{abstract}
Cassava (Manihot esculenta Crantz) is a major staple food crop for more than a billion people in the world. Cassava mosaic virus (CMV), belonging to the Geminiviridae family, is a primary threat to cassava production. Sri Lankan cassava mosaic virus (SLCMV) is the only emergent CMV prevalent in South Asia and Southeast Asia since its identification in 2002. We reported the identification of two invasive strains of SLCMV, Col and HN7, in China in 2018. However, the occurrence and distribution of these known SLCMV strains and the presence of unknown geminivirus in China are still elusive. In this study, we firstly reported an improved CMV detection system based on molecular and serological methods, which was further used to determine the distribution of CMV in major cassava plantations in China. Two optimized PCR primer pairs based on the conserved regions of $A V 1$ and $A C 1$ genes were designed to detect different CMV species and distinguish SLCMV simultaneously. For a serological method, a polyclonal antibody against SLCMV AV1-encoded capsid protein was raised and used for enzyme-linked immunosorbent assay (ELISA). Consistent detection results were achieved by PCR- and ELISA-based methods. Among 62 examined samples collected in 2018, 10 were SLCMV positive, with 4 coinfection cases of two strains (HN7 and Col) in the same cassava plant. Two primer pairs could also be used to detect the presence of CMV in whitefly (Bemisia tabaci) sensitively. All positive samples were from Fujian and Hainan Provinces, indicating a limited distribution of SLCMV in cassava plants in China. Our detection methods could be used for future surveillance system to control and manage cassava mosaic disease in China and other countries.
\end{abstract}

Keywords: Cassava mosaic virus, SLCMV, Whitefly, Detection, Capsid protein, Coinfection

\section{Background}

Cassava (Manihot esculenta Crantz), originally from South America, was introduced into Africa in the sixteenth century (Legg et al. 2015). Since the early twentieth century, cassava has been grown on the African continent due to its ability to withstand difficult growing conditions and its high yield capacity. At present, it is one of the most important staple crops for more than a billion people and is well recognized as a twenty-first century crop for smallholder farmers in developing countries (Chetty et al.

\footnotetext{
* Correspondence: zhangx@im.ac.cn; jianye@im.ac.cn

'State Key Laboratory of Plant Genomics, Institute of Microbiology, Chinese Academy of Sciences, Beijing 100101, China

Full list of author information is available at the end of the article
}

2013). Cassava is also planted for the production of industrial products, like ethanol and starch, in One Belt and One Road countries such as Vietnam, Cambodia, and Sri Lanka (Sarker et al. 2018). According to customs statistics, China imported more than 920 million tons of dry cassava in 2015, mainly from Thailand, Vietnam, Cambodia, Indonesia, and some African countries. It is estimated that total imports of cassava in China and neighboring countries along the border are close to 9 million tons, but there has not been any inspection and quarantine of possible pathogens and pests during the importation of cassava products.

Cassava mosaic disease (CMD), caused by Cassava mosaic virus $(\mathrm{CMV})$, represents the biggest constraint

(c) The Author(s). 2020 Open Access This article is licensed under a Creative Commons Attribution 4.0 International License, which permits use, sharing, adaptation, distribution and reproduction in any medium or format, as long as you give appropriate credit to the original author(s) and the source, provide a link to the Creative Commons licence, and indicate if changes were made. The images or other third party material in this article are included in the article's Creative Commons licence, unless indicated otherwise in a credit line to the material. If material is not included in the article's Creative Commons licence and your intended use is not permitted by statutory regulation or exceeds the permitted use, you will need to obtain permission directly from the copyright holder. To view a copy of this licence, visit http://creativecommons.org/licenses/by/4.0/ 
on cassava production in Africa for decades, and now has reached many countries in Asia (Seif 1982; OtimNape et al. 1997; Wang et al. 2016; Wang et al. 2019a; Chi et al. 2020; Wang et al. 2020). Until now, two species of CMVs have been identified in Asia, i.e., Indian cassava mosaic virus (ICMV) and Sri Lankan cassava mosaic virus (SLCMV) (Saunders et al. 2002; Gao et al. 2010; Wang et al. 2014). SLCMV is now prevalent in Asian countries such as Cambodia, Vietnam, and China, mainly due to the lack of a rapid detection method and virus diagnostic capacity (Uke et al. 2018; Minato et al. 2019; Wang et al. 2019a; Wang et al. 2020). We reported two strains of SLCMV (HN7 and Col) with different virulence in China and explored their pathogenic mechanism (Wang et al. 2020). Understanding the distribution of these two strains and other potential CMVs is essential to prevent a CMD epidemic in China. One problem of CMD prevention is an abundance of whitefly (Bemisia tabaci), a very tiny insect vector of virus transmission that becomes more prevalent during epidemics due to the begomovirus-whitefly mutualism (Colvin et al. 2006; Li et al. 2014; Luan et al. 2014; Zhao et al. 2019).

Detection methods are the first set of tools used to find incursions of quarantine pathogens and are crucial to implement control and eradication of exotic plant disease. There are two common detection methods for plant pathogens, molecular-based and serological-based. Currently, the most common method of CMV detection is to detect viral genomic DNA by PCR or nextgeneration sequencing. Multiplex PCR, which uses several primer pairs targeting different CMV species, is widely used to simultaneously detect various virus species in Africa (Alabi et al. 2008; Aloyce et al. 2013; Mulenga et al. 2016; Otti et al. 2016). However, the PCR-based method sometimes produces false negative or false positive results due to the unspecific amplification with non-optimized PCR primer pairs (Wang et al. 2016; Wang et al. 2019a). The cost of next-generation sequencing is too high, and it is time-consuming when applied to large-scale sample screening. In Asia, geminivirus degenerate primers or specific primers for SLCMV and ICMV are generally used (Duraisamy et al. 2012; Minato et al. 2019), but we and other groups found that the universal geminivirus primer pair (PA/PB) failed to detect SLCMV (Wang et al. 2016; Wang et al. 2019a). A second tool for pathogen detection is based on recognition of viral proteins. Serological methods have been developed to detect viruses in cassava samples using antibodies against viral particles for African cassava mosaic virus (ACMV) (Givord et al. 1994). The antibody against a certain species of CMV cannot be used to detect other species. Detection of SLCMV by serological identification has been rarely reported. The recent rapid expansion of SLCMV in East Asia and Southeast Asia requires suitable diagnostic technologies (Saunders et al. 2002; Chi et al. 2020). For this reason, there is an urgent need to develop an optimized tool to monitor SLCMV.

SLCMV is a bipartite Begomovirus containing two single-stranded circular genomic DNAs. The DNA-A component encodes six proteins: AV1 and AV2 are encoded in virus-sense strands, and the other four proteins, $\mathrm{AC} 1, \mathrm{AC} 2, \mathrm{AC} 3$, and $\mathrm{AC} 4$, are encoded in complementary-sense strands. All of the proteins play important roles in virus survival and host invasion (Fondong 2013). AV1 protein (capsid protein, CP) is the only structural protein and is essential for whitefly transmission among plants (Azzam et al. 1994; Höfer et al. 1997; Hohnle et al. 2001). The viral CP is usually used as an antigen to generate antibodies to detect virus (Hema et al. 2003; Zhang et al. 2018). AC1 is the only essential protein for viral replication in planta (Ruhel and Chakraborty 2019). It has been implicated in the binding of species-specific iteron DNA sequences in the virus common region, illustrating that $\mathrm{AC} 1$ is a conserved protein and also a good species-specific target for distinguishing certain species among multiple CMVs (Fondong 2013).

Here, we developed an efficient detection system for SLCMV for the first time. A total of 62 cassava samples collected from major plantations in China in 2018 were further analyzed with this system. Ten of them from Hainan and Fujian Provinces were found to be infected with at least one strain of SLCMV, and coinfection with two SLCMV strains was also observed in a single cassava plant sample. Our molecular and serological methods are useful for surveillance of SLCMV in China and other countries.

\section{Results}

Design of specific primers for detection of CMV species To design primer pairs for species-specific detection of CMVs, we analyzed the protein-encoded genes in the DNA-A strands of different CMV species. As $A V 1$ genes of various CMV species have higher similarity and $A C 1$ genes have more specificity, we designed UPA/UPB to detect different CMV species and SPA/SPB to specifically detect SLCMV (Additional file 1: Figure S1). Then we evaluated the specificity of these two primer pairs to different CMV species. We extracted total DNA from plants infected by SLCMV-HN7 (MH891840.1), SLCMV-Col (AJ314737.1), ICMV-SG (JX518289.1), and ACMV-NO (AJ427910.1). All DNA samples were adjusted to a concentration of $200 \mathrm{ng} / \mu \mathrm{L}$ and used as templates to conduct PCR assays. The products were analyzed by agarose gel electrophoresis. As the result showed, the primer pair UPA/UPB could amplify products about $700 \mathrm{bp}$ from all CMV-infected samples (Fig. 1a), and SPA/SPB could amplify products approximately $1000 \mathrm{bp}$ only in SLCMVHN7- and SLCMV-Col-infected samples (Fig. 1b). This 
illustrates that the primer pair UPA/UPB could detect different CMV species, whereas SPA/SPB could detect SLCMV specifically.

As the virus-transmitting insect vector is another important factor for plant virus epidemics, it is necessary to develop an efficient and reliable approach to detect it. For this purpose, we tested the specificity of the two primer pairs for CMV detection in its vector, whitefly ( $B$. tabaci). We detected the Q-biotype whitefly (Mediterranean, MED) which fed on SLCMV-Col-infected Nicotiana tabacum for 10 days, and whitefly fed on healthy $N$. tabacum was used as negative control. As Fig. 1c shows, the two primer pairs could amplify corresponding products in whiteflies carrying SLCMV-Col, whereas no amplified products were observed with the negative control samples (Fig. 1c). This result indicates that the primer pairs UPA/UPB and SPA/SPB could be used to detect SLCMV in whitefly.

\section{Detection of CMV from cassava samples by PCR}

As our optimized PCR condition worked very well, we next conducted a field survey on various cassava samples collected from several plantations in China in 2018. A total of 62 cassava samples were collected from five provinces: Guangdong (GD), Guizhou (GZ), Hainan $(\mathrm{HN})$, Guangxi (GX), and Fujian (FJ). PCR analysis showed that 7 out of 32 samples in Hainan Province and 3 out of 11 samples in Fujian Province were infected by SLCMV (Fig. 2a, b). DNA sequencing results demonstrated that 5 positive samples in Hainan were infected by SLCMV-HN7 strain and 1 positive sample in Fujian was infected by SLCMV-Col strain. The remaining samples (HN10, HN24, FJ2, FJ4) were co-infected with SLCMV-HN7 and SLCMV-Col, as the sequencing results showed double peaks at several sites with sequence characteristics of both strains (Fig. 2c and Table 1). Our results suggest that two reported strains of SLCMV (Col and HN7) were the major agents causing CMD in China in 2018. Only samples from two provinces, Hainan and
Fujian, were PCR positive. Coinfection with two SLCMV strains could be observed in some cassava plants.

\section{Generation of SLCMV CP polyclonal antibody}

During field survey and virus detection, we encountered instability, false positive, and false negative results with the single PCR method. To further improve the accuracy of SLCMV detection, we sought to combine the additional serological method with the PCR method. To our knowledge, there is no available commercial antibody for SLCMV detection, so we prepared the antibody against SLCMV CP for detection in cassava samples. We generated the recombinant $\mathrm{CP}$, which is encoded by the AV1 gene of SLCMV-HN7 strain, in Escherichia coli cells. The result of SDS-PAGE showed that $30 \mathrm{kDa}$ recombinant CP was obtained in the supernatant (Fig. 3a). Then we collected the purified recombinant $\mathrm{CP}$ to generate rabbit polyclonal antibody.

To determine the specificity of the SLCMV CP antibody, we conducted Western blot to analyze plants infected by SLCMV-HN7, SLCMV-Col, ICMV-SG, and ACMV-NO. As shown in Fig. 3b, two visible bands were observed on Western blot for SLCMV-HN7- and SLCMV-Col-infected plant samples, whereas no band could be observed for healthy, ICMV-SG- and ACMVNO-infected plant samples (Fig. 3b). We further performed ELISA to detect the samples infected by SLCMV-HN7, SLCMV-Col, ICMV-SG, and ACMV-NO and obtained the same results (Fig. 3c). This indicates that the SLCMV-HN7 CP antibody is specific to SLCMV, but not to the other two CMV species.

\section{Detection of SLCMV in cassava by ELISA}

Subsequently, we used SLCMV CP antibody to detect SLCMV in cassava cultivated in different provinces in China. To verify the PCR results, we carried out ELISA for detection in 14 cassava samples from Hainan and $\mathrm{Fu}-$ jian Provinces (Fig. 4). The results showed that SLCMVpositive samples detected by PCR were also positive by

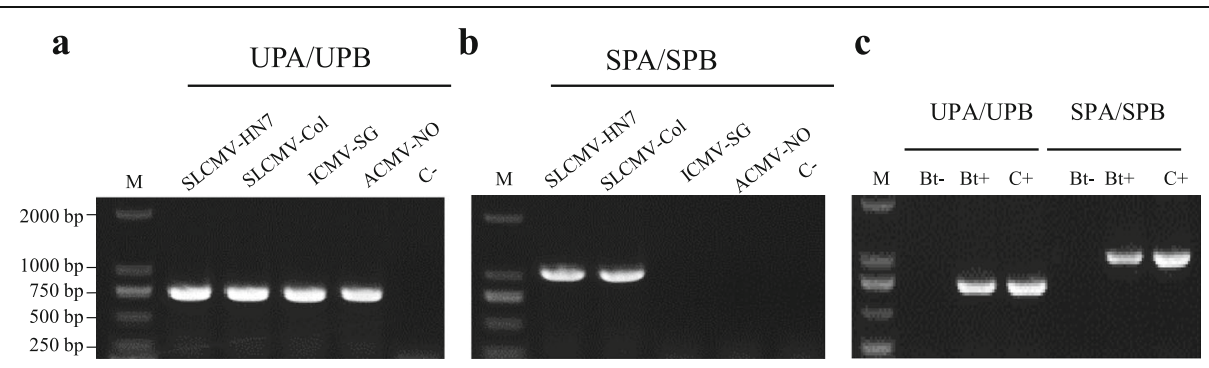

Fig. 1 Optimization of PCR to detect Cassava mosaic virus (CMV) from plants and Q-biotype Bemisia tabaci (Mediterranean, MED). Agarose gel electrophoresis analyzed PCR products amplified from multiple CMVs including Sri Lankan cassava mosaic virus (SLCMV), Indian cassava mosaic virus (ICMV), and African cassava mosaic virus (ACMV) with primer pairs UPAVUPB (a) and SPASPB (b). C-, healthy plant. c DNA gel electrophoresis of PCR products amplified from SLCMV-Col viruliferous Bemisia tabaci with primer pairs UPAVUPB and SPASPB. Bt-, non-viruliferous Bemisia tabaci; Bt+, SLCMV-Col viruliferous Bemisia tabaci; C+, positive control of SLCMV-Col infected plants; M, DNA marker (2000 bp) 


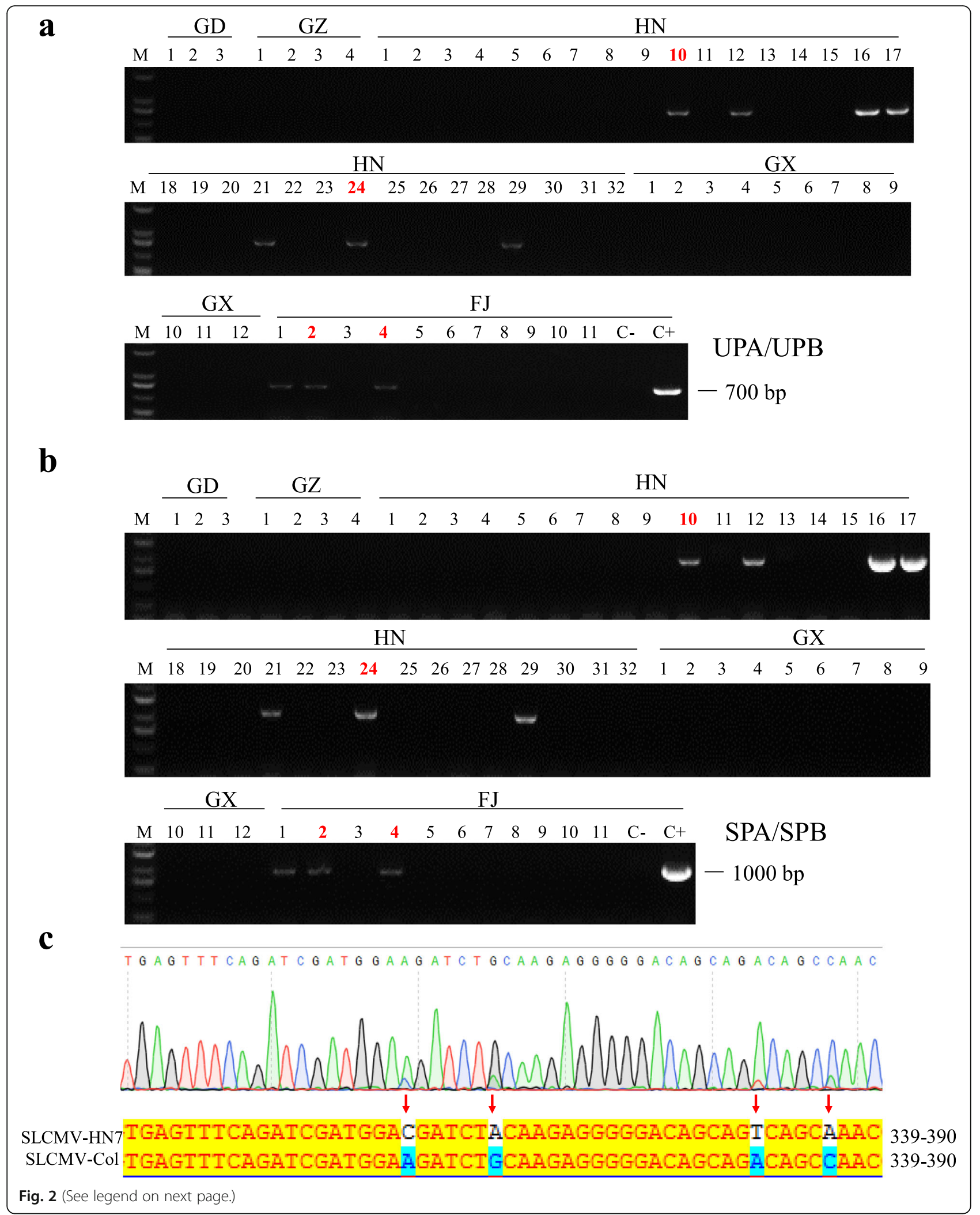


(See figure on previous page.)

Fig. 2 PCR detection of CMV from cassava plantations in China. DNA gel electrophoresis of PCR amplification from cassava samples collected from different provinces in China using primer pairs of UPAVUPB (a) and SPASPB (b). GD, Guangdong Province; GZ, Guizhou Province; HN, Hainan Province; GX, Guangxi Province; FJ, Fujian Province; C-, healthy cassava; C+, SLCMV-Col-infected cassava; M, DNA marker (2000 bp). c DNA sequencing chromatogram of PCR product for a single cassava sample (HN10, HN24, FJ2, or FJ4). A few double peaks in the chromatogram (marked by red arrows in AC1 gene) indicate co-infection of SLCMV-Col and SLCMV-HN7 in a single sample. Alignment of SLCMV-HN7 and SLCMV-Col AC7 nucleotide acid sequence shown in bottom panel

ELISA, which indicates that the combination of PCR and serological methods can provide a more precise detection system for SLCMV detection and surveillance.

\section{Discussion}

In this report, we designed and optimized two primer pairs for the detection of CMV with the PCR method. Then, we established the ELISA method to validate the PCR results. Combined with these two methods, we detected the distribution of CMV in China in 2018. It was demonstrated that there were limited SLCMV invasions of cassava plantations in two provinces, Fujian and Hainan. Our study provides an alternative choice for further development of commercial detection kits suitable for rapid detection of CMV in cassava plantations and customs quarantine.

There are many methods of CMV detection in cassava plantations in Africa, where various CMV species prevail (Appiah et al. 2012; Bulubulu et al. 2015; Mulenga et al. 2016; Uke et al. 2019). Molecular and serological identification techniques gradually came to be used to detect CMV. In Africa, these two techniques are widely applied, especially serological detection, and different kinds of antibodies are prepared for CMV detection by different kinds of ELISA-based methods (Appiah et al. 2012; Bulubulu et al. 2015). In Asia, CMV detection is mostly based on PCR. A few SLCMV AC1 primer pairs were reported (Duraisamy et al. 2012; Minato et al. 2019). In this study, two primer pairs were designed not only to verify the presence of CMV species (primer pair UPA/ UPB based on CMV $A V 1$ gene) but also to distinguish SLCMV specifically (primer pair SPA/SPB based on SLCMV AC1 gene). Duraisamy et al. (2012) detected SLCMV and ICMV with specific primer pairs from $A C 1$ genes, illustrating that the $A C 1$ gene is species-specific and thus a good target for primer design to detect CMV species.

We prepared a polyclonal antibody against SLCMV $\mathrm{CP}$ and confirmed that it can be used for specific detection of SLCMV in Asia. Taking into account the specificity and sensitivity of the antibody in our study, it has potential for developing rapid and reliable commercial kits for SLCMV detection in Asia by further optimizing the currently established method. Moreover, we conducted a field survey with our optimized method and found that coinfection with two SLCMV strains existed in cassava plants in China in 2018 (Table 1). Geminivirus coinfection is frequent in the field, such as mixed infections of two West African tomato-infecting begomoviruses and two strains of Sida golden mosaic virus in Sida jamaicensis plants (Leke and Kvarnheden 2014; Stewart et al. 2014). It was reported that coinfection of plants with multiple plant pathogens resulted in the highest disease prevalence (Susi et al. 2015), as it can increase the chance of virus recombination and evolution. It will be interesting to define the biological significance of coinfection of SLCMV strains in future research.

In Southeast Asia, CMV-derived diseases were reported in two Euphorbiaceae plants, Jatropha curcas and cassava (Wang et al. 2014; Wang et al. 2016). Invasions of SLCMV-HN7 and SLCMV-Col have occurred in China since 2018 (Wang et al. 2020). SLCMV is transmitted via both whitefly and stem cutting. The latter is thought to be responsible for CMD epidemics in Southeast Asia and East Asia in the past 5 years. Previous study revealed that yield loss was greater in cassava plants grown from ACMV-infected stems (55-77\%) than in plants infested by viruliferous whitefly (35-60\%)

Table 1 Number of different SLCMV strains-infected cassavas

\begin{tabular}{lllll}
\hline & SLCMV-HN7 simple infected & SLCMV-Col simple infected & Co-infected & Total samples \\
\hline GD & 0 & 0 & 0 & 3 \\
GZ & 0 & 0 & 0 & 4 \\
HN & 5 & 0 & 2 & 32 \\
GX & 0 & 0 & 0 & 12 \\
FJ & 0 & 1 & 2 & 11 \\
Total SLCMV-infected samples & 5 & 1 & 4 & $10^{\mathrm{a}} / 62^{\mathrm{b}}$ \\
\hline
\end{tabular}

Co-infected: cassava infected by SLCMV-HN7 and SLCMV-Col simultaneously

a number of SLCMV-infected cassavas

${ }^{b}$ number of total detected cassavas 


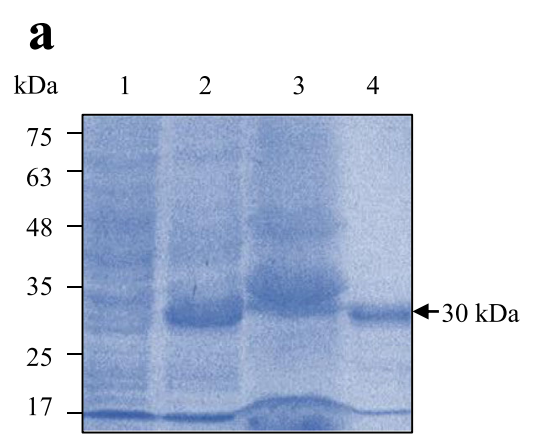

\section{b}

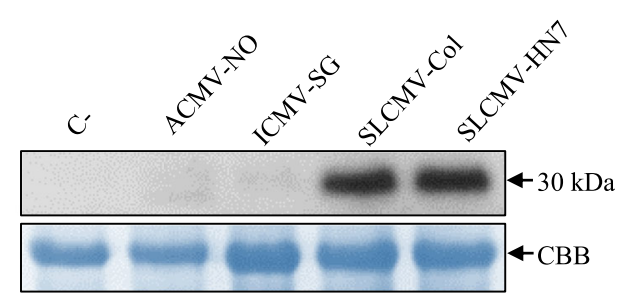

\section{C}

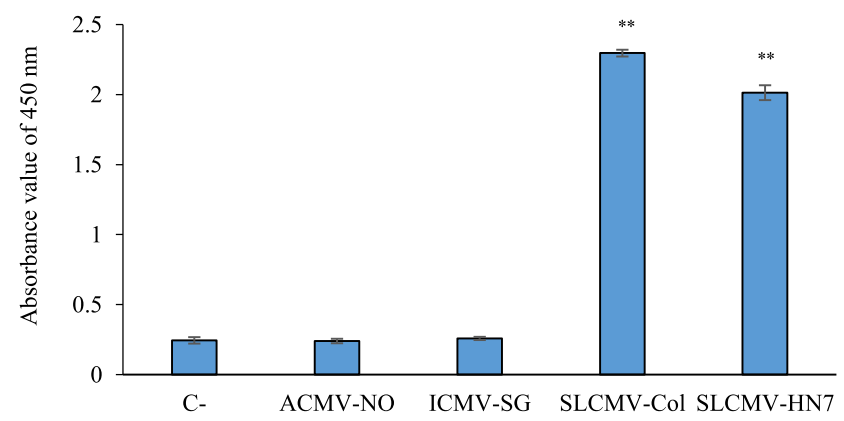

Fig. 3 Protein purification of SLCMV capsid protein (CP) and identification of specificity of CP polyclonal antibody. a Prokaryotic expression and purification of SLCMV-HN7 His-CP recombinant proteins in E. coli. 1: Before induction of CP; 2: supernatant of induced CP with sonication; 3: precipitation of induced CP with sonication; 4: elution of fusion protein. The specificity of CP polyclonal antibody was evaluated by Western blot (b) and ELISA (c). C-, healthy cassava. Values are mean \pm SD $(n=3)$. (Student's t-test; $\left.{ }^{* *} P<0.01\right)$

(Fauquet and Fargette 1990). This indicates that stem cutting is a major form of virus transmission. In this respect, monitoring CMV in cassava plants is necessary to inhibit CMD because cassava is vegetatively propagated through stem cuttings (Legg et al. 2015). Meanwhile, the mutualistic relationship between the insect vector whitefly and some begomoviruses ( $\mathrm{Li}$ et al. 2014; Wang et al. 2019b; Zhao et al. 2019) poses a great threat in terms of future CMD epidemics in Asia and other continents. The successful detection of SLCMV in viruliferous

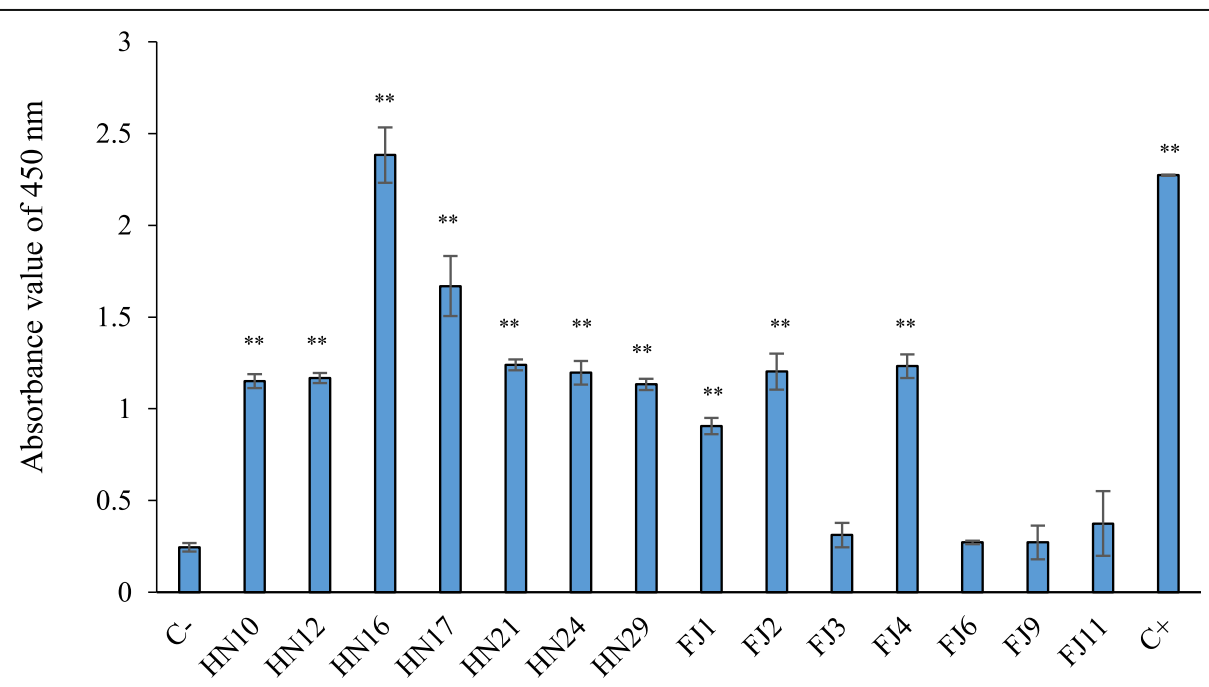

Fig. 4 Cassava samples collected from Hainan and Fujian Provinces in China were analyzed by ELISA using SLCMV CP polyclonal antibody. C-, healthy cassava sample; C+, SLCMV-Col-infected cassava sample. Values are mean \pm SD $(n=3)$. (Student's $t$-test; $\left.{ }^{*} P<0.01\right)$ 
whitefly provides another way for virus detection. Our system could be used in importing quarantine not only in China, but also in other countries in Asia. Our combined detection method would be significant for CMD controlling in Asia.

\section{Conclusions}

In this study, we developed an improved CMV detection system. With this method, limited distribution and coinfection of SLCMV strains in cassava were observed. Moreover, we developed a serological method for ELISA detection. Our optimized detection system paves the way for future SLCMV surveillance in China and other countries.

\section{Methods}

\section{DNA extraction and PCR detection}

Total DNA of cassava leaf from different plantations was extracted by the CTAB method, then used as template for PCR amplification. Total DNA of whitefly was extracted as described previously (Chi et al. 2020). Universal primer pair UPA/UPB was designed according to the conserved sequence of CMV AV1 gene, and SLCMVspecific primer pair SPA/SPB was designed according to the conserved sequence of SLCMV AC1 gene (Additional file 2: Table S1). PCR was conducted on the CFX 96 system (Bio-Rad) using Thunderbird SYBR qPCR mix as described previously (TOYOBO, QPS-201) (Li et al. 2014; Ye et al. 2015).

\section{Generation of CMV-infected plants and acquisition of SLCMV by whitefly}

N. tabacum was infiltrated with Agrobacterium transformed with infectious clones of SLCMV-Col and SLCMV-HN7 as previously described to produce SLCMV-Col- and SLCMVHN7-infected N. tabacum (Wang et al. 2020). Whiteflies were kept on SLCMV-Col-infected N. tabacum for 10 days to obtain SLCMV, and whiteflies kept on healthy N. tabacum served as negative control. ACMV-NO-infected cassava was provided by Prof. Peng Zhang (Institute of Plant Physiology and Ecology, Shanghai Institutes for Biological Sciences, Chinese Academy of Sciences). ICMV-SG-infected $N$. tabacum was obtained by Agrobacterium infiltration using the infectious clone of ICMV-SG retained in our laboratory.

\section{Expression and purification of viral $\mathrm{CP}$}

Based on the nucleotide sequence of the SLCMV DNAA component isolated in China, primer pair AV1-Nde1F/AV1-Xhol-R was designed for the $A V 1$ gene clone (Additional file 2: Table S1). PCR products were cloned into His-tagged prokaryotic expression vector pET-28a with the same restriction sites by the one-step clone method following the manufacturer's protocol (Vazyme, C112-02-AB), and the vector $\mathrm{pET}-28 \mathrm{a}-\mathrm{CP}$ was verified by DNA sequencing.
For $\mathrm{CP}$ protein expression and purification, the pET$28 \mathrm{a}-\mathrm{CP}$ vector was transformed into E. coli BL21 cells, then cultivated in Luria-Bertani (LB) medium with $100 \mu \mathrm{g} / \mathrm{mL}$ kanamycin at $37^{\circ} \mathrm{C}$. Before induction, $100 \mu \mathrm{L}$ of cell suspension was extracted to detect total protein. After $12 \mathrm{~h}$ of induction by isopropylthio- $\beta$-D-thiogalactoside (IPTG, final concentration of $0.15 \mathrm{mM}$ ), the bacteria were collected and resuspended in $\mathrm{T}$ buffer containing $20 \mathrm{mM}$ Tris- $\mathrm{HCl}$ (pH 8.0), $500 \mathrm{mM} \mathrm{NaCl}$, $10 \%$ glycerol, $0.1 \%$ Triton X-100, and $1 \mathrm{mM}$ PMSF, then lysed by sonication on ice. After centrifugation at 12 , $000 \times \mathrm{g}$ for $30 \mathrm{~min}$ at $4{ }^{\circ} \mathrm{C}$, the supernatant was collected and recombinant proteins were purified using a Ni-NTA agarose affinity column (Bio-Rad). After washing with an increasing concentration gradient of imidazole $(20,60$, $100,200,300$, and $400 \mathrm{mM}$ ), proteins eluted in $\mathrm{T}$ buffer containing $200 \mathrm{mM}$ imidazole were collected, then concentrated with Amicon-Ultra-10 filters (Millipore). The purified recombinant $\mathrm{CP}$ protein was used to generate rabbit polyclonal antibody.

\section{Enzyme-linked immunosorbent assay (ELISA)}

For detection of cassava samples by ELISA, $0.1 \mathrm{~g}$ cassava samples collected from Hainan and Fujian Provinces were ground into powder, then diluted using $500 \mu \mathrm{L}$ of antigencoating solution $\left(1.59 \mathrm{~g}\right.$ of $\mathrm{NaCO}_{3}, 2.93 \mathrm{~g}$ of $\mathrm{NaHCO}_{3}$, add water to $1 \mathrm{~L}, \mathrm{pH}=9.6$ ). After mixing, $100 \mu \mathrm{L}$ was drawn into a 96-well plate for antigen immobilization at $4{ }^{\circ} \mathrm{C}$ overnight. Next, the plate was washed 3 times using PBST buffer $\left(8.0 \mathrm{~g}\right.$ of $\mathrm{NaCl}, 2.9 \mathrm{~g}$ of $\mathrm{Na}_{2} \mathrm{HPO}_{4} \cdot 12 \mathrm{H}_{2} \mathrm{O}, 0.2 \mathrm{~g}$ $\mathrm{KH}_{2} \mathrm{PO}_{4}, 0.2 \mathrm{~g}$ of $\mathrm{KCl}, 0.5 \mathrm{~mL}$ of Tween-20, add water to $1 \mathrm{~L})$. Then, $100 \mu \mathrm{L}$ of blocking buffer (5\% dried skimmed milk in PBST buffer) was added to cover all unsaturated surface-binding sites of the wells at $37^{\circ} \mathrm{C}$ for $2 \mathrm{~h}$. The plate was washed 3 times using PBST buffer, then incubated with CP antibody, which was diluted in PBST buffer at 1: 5000 for $2 \mathrm{~h}$. The plate was washed 3 times using PBST buffer and anti-rabbit antibody (A2556, SIGMA) was added and incubated for $2 \mathrm{~h}$. Then the plate was washed 3 times using PBST buffer and $100 \mu \mathrm{L}$ substrate buffer $(10$ $\mathrm{mL}$ diethanolamine added to $90 \mathrm{~mL}$ of water, $\mathrm{pH}=9.8$, then disodium 4-nitrophenylphosphate added to a final concentration of $1 \mathrm{mg} / \mathrm{mL}$ ) was added to react. After 15 min, the reaction signal was obtained by the scanner (Tecan IF M200 Pro) at $\mathrm{OD}_{450}$.

\section{Supplementary information}

Supplementary information accompanies this paper at https://doi.org/10. 1186/s42483-020-00063-w.

Additional file 1: Figure S1. Schematic diagram of specific primer design for CMVs UPA/UPB (a) and SLCMV SPA/SPB (b).

Additional file 2: Table S1. Primers used in this study. 


\section{Abbreviations}

ACMV: African cassava mosaic virus; CMD: Cassava mosaic disease; CMV: Cassava mosaic virus; CP: Capsid protein; ELISA: Enzyme-linked immunosorbent assay; ICMV: Indian cassava mosaic virus; SLCMV: Sri Lankan cassava mosaic virus

\section{Acknowledgments}

The authors would like to thank Prof. Peng Zhang (Institute of Plant Physiology and Ecology, Shanghai Institutes for Biological Sciences, Chinese Academy of Sciences) for providing ACMV-NO-infected cassava plants.

\section{Authors' contributions}

DW, XZ and JY conceived and designed the experiments; DW performed the experiments; DW and XZ analyzed the data; GH, TS and GW provided cassava samples which were collected from different provinces in China; DW and $X Z$ wrote the paper; JY and RF edited the manuscript. All authors read and approved the final manuscript.

\section{Funding}

This work was supported by the National Science Foundation of China (31830073, 31672001 and 31901853), and National key research and development program (2018YFD0201503).

\section{Availability of data and materials}

The datasets used and/or analyzed in the current study are available from the corresponding author on reasonable request

\section{Ethics approval and consent to participate}

Not applicable.

\section{Consent for publication}

Not applicable.

\section{Competing interests}

The authors declare that they have no competing interests

\section{Author details}

'State Key Laboratory of Plant Genomics, Institute of Microbiology, Chinese Academy of Sciences, Beijing 100101, China. ${ }^{2}$ CAS Center for Excellence in Biotic Interactions, University of Chinese Academy of Sciences, Beijing 100049, China. ${ }^{3}$ Environment and Plant Protection Institute, Chinese Academy of Tropical Agricultural Sciences, Haikou, Hainan, China.

\section{Received: 30 April 2020 Accepted: 16 July 2020}

Published online: 03 August 2020

\section{References}

Alabi OJ, Kumar PL, Naidu RA. Multiplex PCR for the detection of African cassava mosaic virus and East african cassava mosaic Cameroon virus in cassava. J Virol Methods. 2008:154:111-20.

Aloyce RC, Tairo F, Sseruwagi P, Rey MEC, Ndunguru J. A single-tube duplex and multiplex PCR for simultaneous detection of four cassava mosaic begomovirus species in cassava plants. J Virol Methods. 2013;189:148-56.

Appiah AS, Amoatey HM, Klu GYP, Afful NT, Azu E, Owusu GK. Spread of African cassava mosaic virus from cassava (Manihot esculenta Crantz) to physic nut (Jatropha curcas L.) in Ghana. J Phytopathol. 2012;4:31-7.

Azzam O, Frazer J, de la Rosa D, Beaver JS, Ahlquist P, Maxwell DP. Whitefly transmission and efficient SsDNA accumulation of bean golden mosaic geminivirus require functional coat protein. Virology. 1994;204:289-96.

Bulubulu OF, Diamuini NA, Kikakedimau NR, Mbaya NA, Mutambel H, Lumande K, et al. PCR and ELISA detection of cassava mosaic virus in a Congolese cassava landrace. Int J Biotechnol Food Sci. 2015;3:10-6.

Chetty CC, Rossin CB, Gruissem W, Vanderschuren H, Rey MEC. Empowering biotechnology in southern Africa: establishment of a robust transformation platform for the production of transgenic industry-preferred cassava. New Biotechnol. 2013;30:136-43.

Chi Y, Pan L-L, Bouvaine S, Fan Y-Y, Liu Y-Q, Liu S-S, et al. Differential transmission of Sri Lankan cassava mosaic virus by three cryptic species of the whitefly Bemisia tabaci complex. Virology. 2020;540:141-9.

Colvin J. Omongo CA, Govindappa MR, Stevenson PC, Maruthi MN, Gibson G, et al. Host-plant viral infection effects on arthropod-vector population growth, development and behaviour: management and epidemiological implications. Adv Virus Res. 2006;67:419-52.

Duraisamy R, Natesan S, Muthurajan R, Gandhi K, Lakshmanan P, Karuppusamy N, et al. Molecular studies on the transmission of Indian cassava mosaic virus (ICMV) and Sri Lankan cassava mosaic virus (SLCMV) in cassava by Bemisia tabaci and cloning of ICMV and ICMV replicase gene from cassava. Mol Biotechnol. 2012;53:150-8.

Fauquet C, Fargette D. African cassava mosaic virus: etiology, epidemiology, and control. Plant Dis. 1990:74:404-11.

Fondong VN. Geminivirus protein structure and function. Mol Plant Pathol. 2013; 14:635-49.

Gao S, Qu J, Chua N-H, Ye J. A new strain of Indian cassava mosaic virus causes a mosaic disease in the biodiesel crop Jatropha curcas. Arch Virol. 2010;155 607-12.

Givord L, Fargette D, Kounounguissa B, Thouvenel JC, Walter B, Regenmortel MV. Detection of geminiviruses from tropical countries by a double monoclonal antibody ELISA using antibodies to African cassava mosaic virus. Agronomie. 1994;14:327-33.

Hema M, Kirthi N, Sreenivasulu P, Savithri HS. Development of recombinant coat protein antibody based IC-RT-PCR for detection and discrimination of sugarcane streak mosaic virus isolates from southern India. Arch Virol. 2003; 148:1185-93.

Höfer P, Bedford ID, Markham PG, Jeske H, Frischmuth T. Coat protein gene replacement results in whitefly transmission of an insect nontransmissible geminivirus isolate. Virology. 1997;236:288-95.

Hohnle M, Höfer P, Bedford ID, Briddon RW, Markham PG, Frischmuth T. Exchange of three amino acids in the coat protein results in efficient whitefly transmission of a nontransmissible abutilon mosaic virus isolate. Virology. 2001;290:164-71

Legg JP, Kumar PL, Makeshkumar T, Tripathi L, Ferguson M, Kanju E, et al. Cassava virus diseases: biology, epidemiology, and management. Adv Virus Res. 2015; 91:85-142.

Leke WN, Kvarnheden A. Mixed infection by two West African tomato-infecting begomoviruses and ageratum leaf curl Cameroon betasatellite in tomato in Cameroon. Arch Virol. 2014;159:3145-8.

Li R, Weldegergis BT, Li J, Jung C, Qu J, Sun Y, et al. Virulence factors of geminivirus interact with myc2 to subvert plant resistance and promote vector performance. Plant Cell. 2014;26:4991-5008.

Luan J-B, Wang X-W, Colvin J, Liu S-S. Plant-mediated whitefly-begomovirus interactions: research progress and future prospects. Bull Entomol Res. 2014; 104:267-76.

Minato N, Sok S, Chen S, Delaquis E, Phirun I, Le VX, et al. Surveillance for Sri Lankan cassava mosaic virus (SLCMV) in Cambodia and Vietnam one year after its initial detection in a single plantation in 2015. PLoS One. 2019;14 e0212780.

Mulenga RM, Legg JP, Ndunguru J, Miano DW, Mutitu EW, Chikoti PC, et al. Survey, molecular detection, and characterization of geminiviruses associated with cassava mosaic disease in Zambia. Plant Dis. 2016;100:1379-87.

Otim-Nape GW, Thresh JM, Shaw MW. The effects of cassava mosaic virus disease on yield and compensation in mixed stands of healthy and infected cassava. Ann Appl Biol. 1997;130:503-21.

Otti G, Bouvaine S, Kimata B, Mkamillo G, Kumar PL, Tomlins K, et al. High-throughput multiplex real-time PCR assay for the simultaneous quantification of DNA and RNA viruses infecting cassava plants. J Appl Microbiol. 2016;120:1346-56.

Ruhel R, Chakraborty S. Multifunctional roles of geminivirus encoded replication initiator protein. Virus Disease. 2019;30:66-73.

Sarker MNI, Hossin MA, Yin X, Sarkar MK. One belt one road initiative of China: implication for future of global development. Mod Econ. 2018;9:623-38.

Saunders K, Salim N, Mali VR, Malathi VG, Briddon R, Markham PG, et al. Characterisation of Sri lankan cassava mosaic virus and Indian cassava mosaic virus: evidence for acquisition of a DNA B component by a monopartite begomovirus. Virology. 2002;293:63-74.

Seif AA. Effect of cassava mosaic virus on yield of cassava. Plant Dis. 1982;66:661-2.

Stewart C, Kon T, Rojas M, Graham A, Martin D, Gilbertson R, et al. Mixed infection of Sida jamaicensis in Jamaica reveals the presence of three recombinant begomovirus DNA a components. Arch Virol. 2014;159:2509-12.

Susi H, Barrès B, Vale PF, Laine A-L. Co-infection alters population dynamics of infectious disease. Nat Commun. 2015:6:5975.

Uke A, Hoat TX, Quan MV, Liem NV, Ugaki M, Natsuaki KT. First report of Sri Lankan cassava mosaic virus infecting cassava in Vietnam. Plant Dis. 2018;102: 2669. 
Uke A, Khin S, Kitaura K, Ugaki M, Natsuaki KT. Combination of an image-posting system and molecular diagnosis for detecting Sri Lankan cassava mosaic virus. Trop Plant Pathol. 2019;44:238-43.

Wang D, Yao XM, Huang GX, Shi T, Wang GF, Ye J. First report of Sri Lankan cassava mosaic virus infected cassava in China. Plant Dis. 2019a;103:1437.

Wang D, Zhang X, Yao X, Zhang P, Fang R, Ye J. A 7-amino-acid motif of rep protein essential for virulence is critical for triggering host defense against Sri Lankan cassava mosaic virus. Mol Plant-Microbe Interact. 2020;33:78-86.

Wang G, Sun YW, Xu RR, Qu J, Tee CS, Jiang XY, et al. DNA-A of a highly pathogenic Indian cassava mosaic virus isolated from Jatropha curcas causes symptoms in Nicotiana benthamiana. Virus Genes. 2014;48:402-5.

Wang HL, Cui XY, Wang XW, Liu SS, Zhang ZH, Zhou XP. First report of Sri Lankan cassava mosaic virus infecting cassava in Cambodia. Plant Dis. 2016; 100:1029

Wang N, Zhao P, Ma Y, Yao X, Sun Y, Huang X, et al. A whitefly effector Bsp9 targets host immunity regulator WRKY33 to promote performance. Philos Trans R Soc B. 2019b;374:20180313.

Ye J, Yang J, Sun Y, Zhao P, Gao S, Jung C, et al. Geminivirus activates asymmetric leaves 2 to accelerate cytoplasmic DCP2-mediated mRNA turnover and weakens rna silencing in Arabidopsis. PLoS Pathog. 2015;11:e1005196.

Zhang M, Chen R, Zhou X, Wu J. Monoclonal antibody-based serological detection methods for wheat dwarf virus. Virol Sin. 2018:33:173-80.

Zhao P, Yao X, Cai C, Li R, Du J, Sun Y, et al. Viruses mobilize plant immunity to deter nonvector insect herbivores. Sci Adv. 2019;5:eaav9801.

Ready to submit your research? Choose BMC and benefit from:

- fast, convenient online submission

- thorough peer review by experienced researchers in your field

- rapid publication on acceptance

- support for research data, including large and complex data types

- gold Open Access which fosters wider collaboration and increased citations

- maximum visibility for your research: over $100 \mathrm{M}$ website views per year

At $\mathrm{BMC}$, research is always in progress.

Learn more biomedcentral.com/submissions 